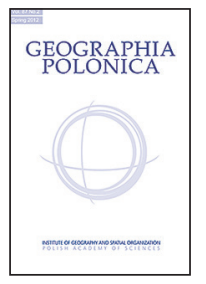

\title{
THE INTERDEPENDENCE BETWEEN SUBURBAN ENCLAVES AND THE ROAD NETWORK IN THE DEVELOPMENT PROCESS: A CASE STUDY IN POLAND
}

\author{
Ada Wolny • Ryszard Źróbek \\ University of Warmia and Mazury in Olsztyn \\ Faculty of Geodesy, Geospatial and Civil Engineering \\ Department of Real Estate Resources \\ ul. Oczapowskiego 2, 10- 720 Olsztyn: Poland \\ e-mails: ada.wolny@uwm.edu.pl•rzrobek@uwm.edu.pl
}

\begin{abstract}
The aim of this article is to present the dependence between the suburban development of housing estates and the transportation system. Relationships between the city and its surroundings depend on the road network and daily traffic. That is why in most cases cities 'spread' in a linear form - forming an 'urban sprawl' with a low density of development and long distances between housing and retail services.

According to analyses, cities in Poland affect their outskirts in an 'urban sprawl' manner. The development of suburban housing dependent on communications leads to spatial conflicts. This article shows both the interdependence and consequences of this situation. The main methods used were statistical and spatial analyses and a case study.
\end{abstract}

\section{Key words}

urban sprawl $\bullet$ transportation $\bullet$ land use $\bullet$ expansion $・$ development $\bullet$ spatial conflicts

\section{Introduction}

The expansion of a city into areas neighbouring its borders reflects the development of settlements and the influx of urban residents to the suburbs. Timár and Váradi (2001) consider suburbanisation, on the urban scale, to be the decentralisation of urban population, capital and human activities. Although the people who originally moved to the suburbs were from the middle class, it was never exclusively a middle-class process nor is it necessarily even a class process (Butler 2007). Urbanisation in Communist countries was characterised by the concentration of investments and growth into medium and large cities and within their territories into large housing and industrial complexes at their urban edges (Sýkora \& Ouředníček 2007). This has also been observed in Poland. 
However, one-hundred-thousand cities and their metropolitan areas are, regarding the population, economy and function, very important parts of the settlement systems of most other post-socialist European countries (Kubeš 2015).

The main causes of this city expansion are the dispersion of built-up areas as well as increases in the costs of transportation, infrastructure and in terms of nature conservation. There is a threat of the uncontrolled spread of development as a result of suburbanisation processes, particularly in suburban municipalities.

Moreover, the development of areas in the city's suburbs is conditioned by interdependencies that occur between the city, including its central hub and immediate surroundings, and the municipalities located in its hinterland. Interactions between the economic functions of the city and rural areas as well as interactions between the elements of space in the form of the settlement network or infrastructure may be observed in this area (Bański 2006). Various functional interdependencies evolved between the city and its surroundings (Burneika \& Ubarevičienè 2015).

In the late 1990s the construction of single family houses in the hinterland of larger cities was significantly expanded in the Czech Republic, Slovakia, Hungary, Slovenia, the Baltic States, and to some extent in Poland. Houses were especially built for younger, welleducated, and financially secure couples with children, who decided to move out from the city. They were looking for a quiet, more natural and more comfortable lifestyle in houses with gardens (Kubeš 2015). This tendency has led to the growth of enclaves with suburban family houses which has been observed over the last three decades.

As Polish cities 'spread', in most cases in a linear form, a process defined as urban sprawl is observed. According to Chin (2002) it is based on the degree of continuity in development - from a more dense to a more distributed development - because the sprawl of the city is a matter of degree, not an absolute form. Still, typical suburbia did not come into existence in the areas around Poland's large cities; instead, there exists a wide scattering of usually small housing estates, groups of several homes, or even single residential buildings, whose presence is a reflection of inadequate control over rapidly-developing areas of construction (Degórska 2012).

The main features of this process, according to which the area of urban sprawl may be identified in space (Galster et al. 2001; Lorens 2005; Thompson 2013) are:

- significant distance between different forms of land use,

- low development density,

- lack of continuity and uniformity of land use,

- single land uses and rigorously separated uses (e.g. long distances between housing and retail),

- local concentration of land use,

- low centrality of spatial organization,

- past existing built-up areas, leaving undeveloped gaps,

- dependency on automobiles,

- the pursuit of developers and investors in the development of land which is more easily accessible (quality and price).

This list emphasises the dispersion, the linear character of development and the importance of accessibility. Considering the above, as the distance from the city core increases different phases of urban sprawl may be observed. In the standard monocentric framework, all workers commute to a unique central location to work and choose a residential location based on the trade-off between lost wages due to travel time and their preference for space (Baum-Snow 2007). Initially, linear development is concentrated along easily accessible public roads - main roads (usually primary and secondary) and motorways. In the second phase, new local roads are constructed in order to lead to new built-up areas. The diagram that characterises the three phases of this process is presented in Figure 1.

Concern over urban sprawl is at least in part a concern over dispersed, low-density residential development patterns in suburban and ex-urban locations (McConnell et al. 2006). 


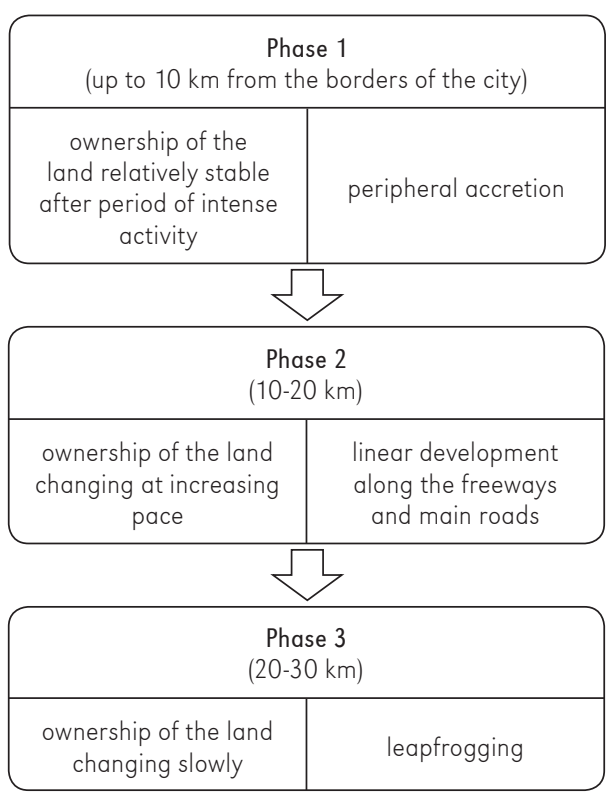

Figure 1. Phases of urban sprawl process

Despite the high investment potential of the city centres, investing outside the cities is easier and less expensive, so we may observe a progressive sprawl of suburbs and dispersed housing in rural areas (Kronenberg \& Bergier 2010). Urban sprawl accompanied by the development of residential, service and industrial functions as well as technological infrastructure leads to changes in land use structure. There is a continuous increase in the area of land use patterns characteristic of urban areas (Senetra et al. 2014).

As was noted, land use allocation in the suburbs depends on four elements: cellular accessibility, based on zonal accessibility levels by car and public transport for different activities, and local distances to road and rail infrastructure, railway stations, motorway accesses and exits; physical suitability as described in national and regional land use policy plans; and the neighbourhood effect, which is the combined effect of attraction and repulsion as a function of the distance separating the different functions within the neighbourhood (Geurs \& van Wee 2006). Commuting is related to the processes of population and employment redistribution. There are two basic causes for commuting: people change their place of residence but not their job, or people change their job (or enter the labour market) but not their place of residence (Tammaru 2005). In recent years it has turned out that one of the solutions to the problem of urban sprawl and the compact city is not planningrelated; rather, it focuses on demographic and lifestyle changes (Kotus 2006).

In particular, the first example cited by Tammaru (2005) results in transportation development. Following this, the capacity of 'communication arteries' leading to the city must be increased with the growing number of 'travel-to-work' commuters. The new highways are likely to have had a significant impact on central city populations (Baum-Snow 2007) as well as the population in the suburbs. That is why accessibility by the transportation system has a significant impact on the development of the suburbs. This accessibility might be defined as the extent to which landuse and transport systems enable (groups of) individuals to reach activities or destinations by means of a (combination of) transport mode(s) (Geurs \& van Wee 2004). According to Rosik and Stępniak (2015) the accessibility indicator might be considered as the sum of the mass of each separate region divided by the shortest travel time to it. That is why this travel time has an important role in the research conducted.

Taking into account the above, this paper discusses the interdependence of the development of suburban housing estates and road communications as a substantial aspect of the urban sprawl process in Poland. The study has been conducted under circumstances described in the following methodology. The research area has been selected and also described.

\section{Methodology and characteristics of the research area}

As 'suburban sprawl' is one of the relevant problems associated with development, there is a great need to apply a variety of methods and approaches to analyse this process. 
The aim of this article is to identify the dependence between the development of housing estates and transportation systems within Polish suburbs. Taking this objective into account, the research procedure includes:

1. A study of literature on the subject (defining processes of suburbanisation in different spheres and the selection of the main features of urban sprawl);

2. The selection of objects for research: the surroundings of cities with a population between 100,000 and 300,000 as well as the different regional functions of these cities;

3. Selection of the main indicators taken into account in analyses;

4. Gathering and integrating data crucial for the analyses;

5. Application of spatial analyses with the use of GIS software;

6. Case study analysis - identifying spatial conflicts caused by the transformation of a communications system within the suburbs.

The study is based on empirical analyses - statistical and spatial analyses and a case study. Most of the results obtained are presented graphically.

As a result of the selection of the objects of the research, three cities were chosen along with the functional area surrounding them within an average travel distance along routes to the city of less than 30 minutes. The functionality of web services such as Google Maps was used in order to determine the distances. Moreover, the area of research has been customised to the administrative borders of municipalities within the specified ranges. The chosen cities are:

- Olsztyn - located in the northern part of Poland, in the Polish lakeland, the capital of the Warmia and Mazury Province, with 173,831 citizens - according to data obtained from the Central Statistical Office of Poland on 31 December 2014 (CSO 2014),

- Torun - located on the shores of the Vistula River at the beginning of the northern part of its course, it is the seat of the local government administration of the KuyavianPomeranian Province, with 203,158 citizens
- according to data obtained from Central Statistical Office of Poland on 31 December 2014 (CSO 2014),

- Płock - located on the shores of the Vistula River along the central part of its course, a city with district rights in Mazovian Province, with 122,224 citizens - according to data from Central Statistical Office of Poland on 31 December 2014 (CSO 2014).

The main criterion for selection is the city's population, but the administrative functions of cities and the regional traffic situation are equally important. This is especially true of the capacity of regional and local transportation systems to affect the daily travel routes mainly by expanding the distances measured in kilometres.

Moreover, taking into account the development of suburban housing estates, the main indicators of these developments have been selected for each municipality. These indicators are listed below:

- increase in the number of residential buildings,

- number of dwellings handed over for occupation,

- land use plans - the total number and the area of the plan as a proportion of the whole municipal area,

- number of decisions on building conditions. The study covers the period from 2010 to 2014. In order to calculate and present the results, the necessary statistical data was collected from CSO - the Local Data Bank (LDB 2015). Detailed results are presented on a cartographic background including administrative borders (CODGK 2015) and communication systems (OSM 2015).

Therefore, the detailed analyses made in the article include the application of the cartogram and cartodiagram method with the use of QGIS software. The resulting maps contain the spatial distribution of values of the selected indicators for every part of the area of research.

Finally, case study analysis is used to describe the spatial conflict caused by the construction of a ring road in the suburbs of Olsztyn. 


\section{Results and discussion}

Polish suburbs have seen the rapid development of housing estates during the past few years, which are spread around the majority of Polish cities. For the purpose of this paper, only a few significant examples of cities were analysed, each with a population between 100,000 and 300,000 , where the interdependence between the development of transportation systems and housing estates occurred. These cities are Olsztyn, Toruń and Płock with their similarities and differences.

The authors decided to select or create indicators in order to describe the development of housing estates in the suburbs of Olsztyn, Torun and Płock. The data has been received from the CSO - the Local Data Bank. This selection was primarily based on the experience of the researchers, as well as the results of the previous studies conducted on similar subjects. The indicators chosen are listed below:

- increase in the number of residential buildings between 2010 and 2014,
- number of apartments handed over for occupation - total number over a period of 5 years,

- land use plans - the total number of plans in 2014 and the area of the plan as a proportion of the whole municipal area in 2014,

- number of decisions on building conditions for residential buildings - the total number for a period of 5 years (2010-2014).

It should be pointed out that the indicators have been calculated or selected for every municipality within a range of up to $30 \mathrm{~min}$ utes from the city core. The indicators have been visualized on a cartographic background with the municipal boundaries and including transportation systems within the area of research. In order to prepare spatial analyses, QGIS software was used and the results are presented in Figures 2a,b,c - 4a,b,c. Cartograms divide specified values into ranges with a number from 4 to 6 depending on the range of indicator values.

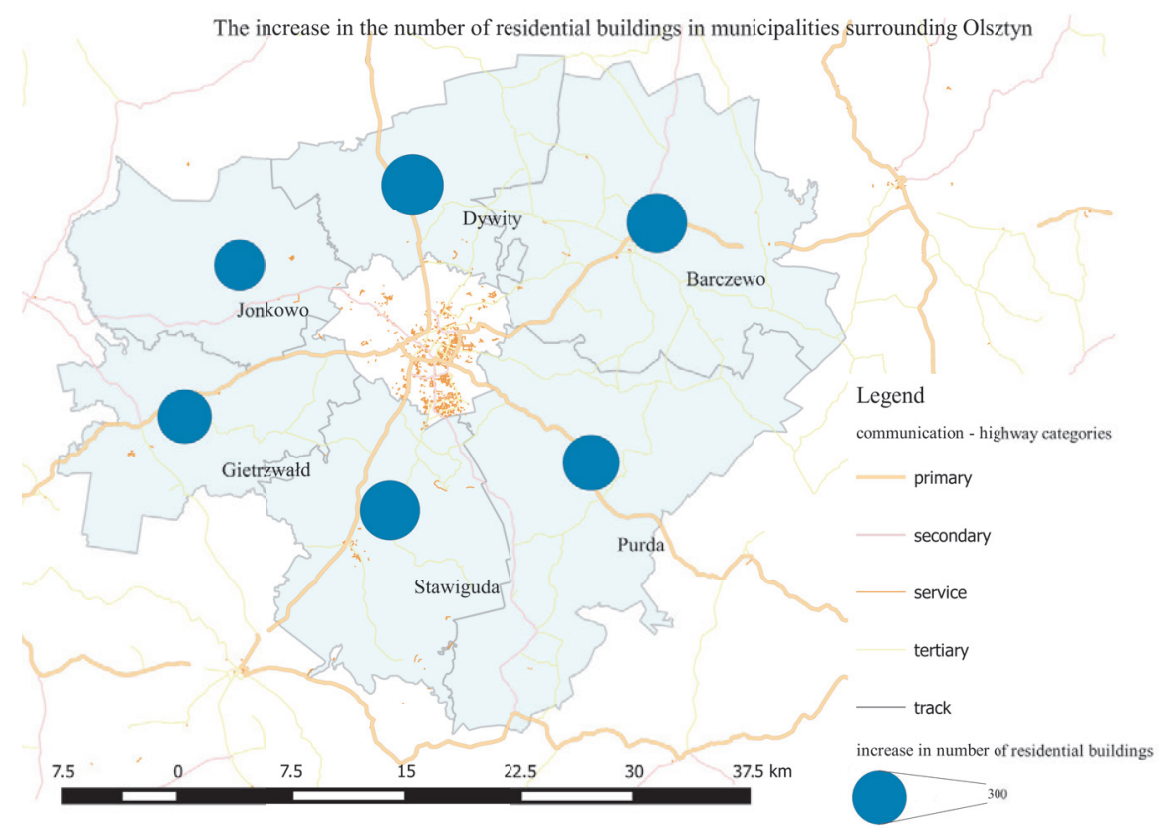

Figure 2a. The increase in the number of residential buildings between 2010 and 2014 


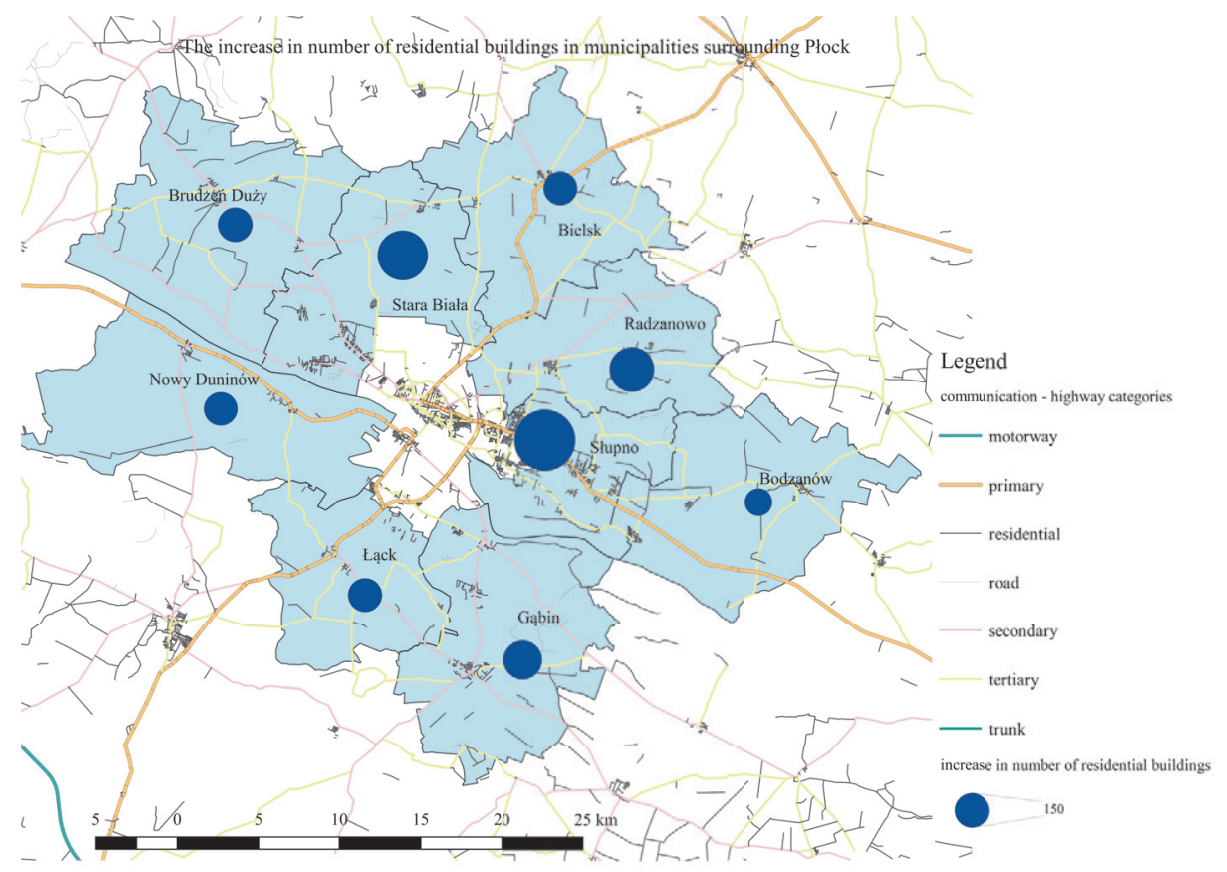

Figure 2b. The increase in the number of residential buildings between 2010 and 2014

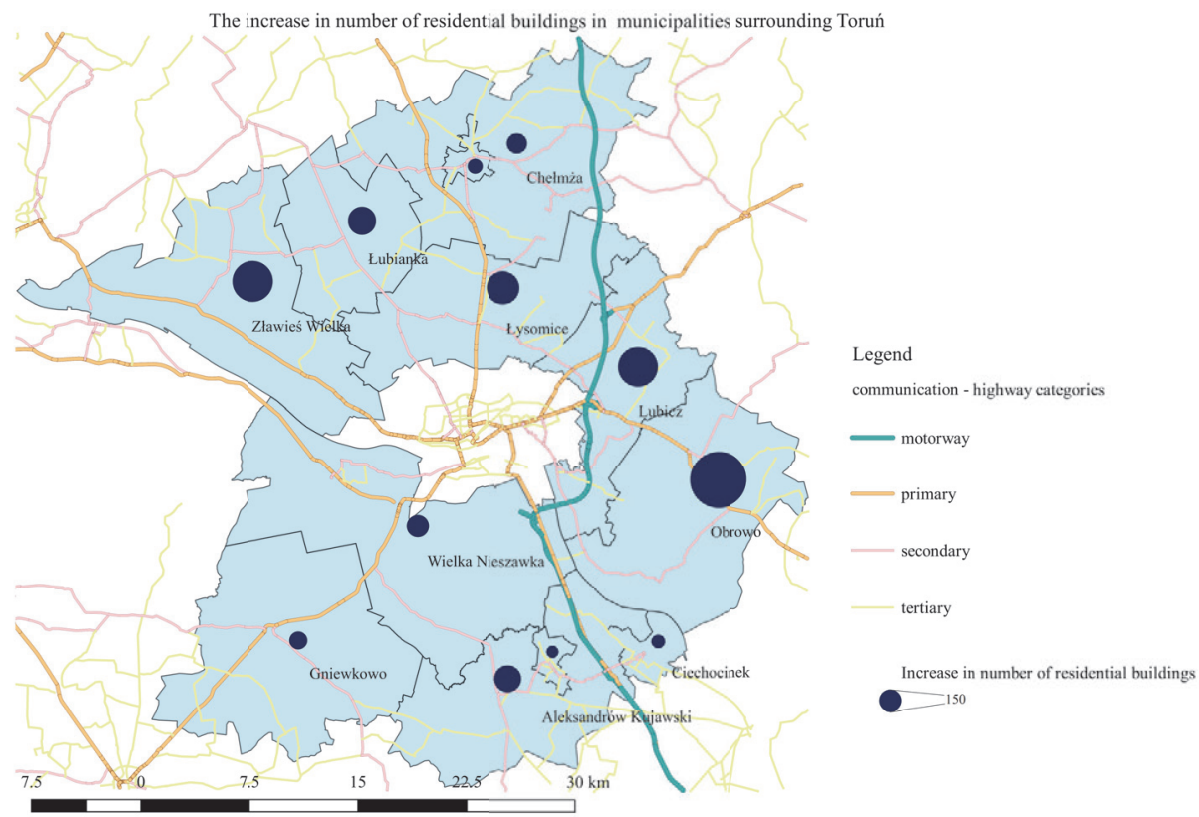

Figure 2c. The increase in the number of residential buildings between 2010 and 2014 
The increase in the number of residential buildings between 2010 and 2014 is most evident in 3 municipalities surrounding Olsztyn (Dywity, Stawiguda and Barczewo) where the increase is in the range of 360-390 buildings (Fig. 2a). Moreover, a high value of this indicator is observed in the municipality of Słupce, neighbouring Płock on the east side (range of 370-460 buildings) and Stara Biała in the north - west (range of values of 280-370). They are presented in Figure $2 \mathrm{~b}$. The highest values of this indicator are reported in Obrowo, a municipality near Torun (Fig. 2c). The increase in the number of residential buildings is 987 , which is at least two times larger than in other municipalities. Every municipality with high values of this indicator is either neighbouring the city core or has good communications with this city. Most of them are on the primary routes and Obrowo is also located near the A1 motorway. It might be stated that the accessibility of these municipalities to the transportation system is above average.
In the next part of this presentation of the research results the values for the number of apartments handed over for occupation during the period of 5 years (2010-2014) are presented. The municipality that reported the highest value of this indicator in the suburbs of Olsztyn is Stawiguda, adjoining the city on the south side (Fig. $3 a$ ). The number of apartments handed over for occupation during the 5-year period reached the range of 705-820. The highest value of this indicator is once more observed in Obrowo (Fig. 3c), where the number of completed apartments is 1000. In the suburbs of Płock, the values reported for this indicator are three times lower. During the period between 2010 and 2014 more than 330 apartments were handed over for occupation in the area of the municipalities of Słupno, Stara Biała and Gabin (Fig. 3b). Only the last one does not have a good quality transportation system.

It should be emphasised that the results of the development of housing estates in the suburbs do not only form the subject

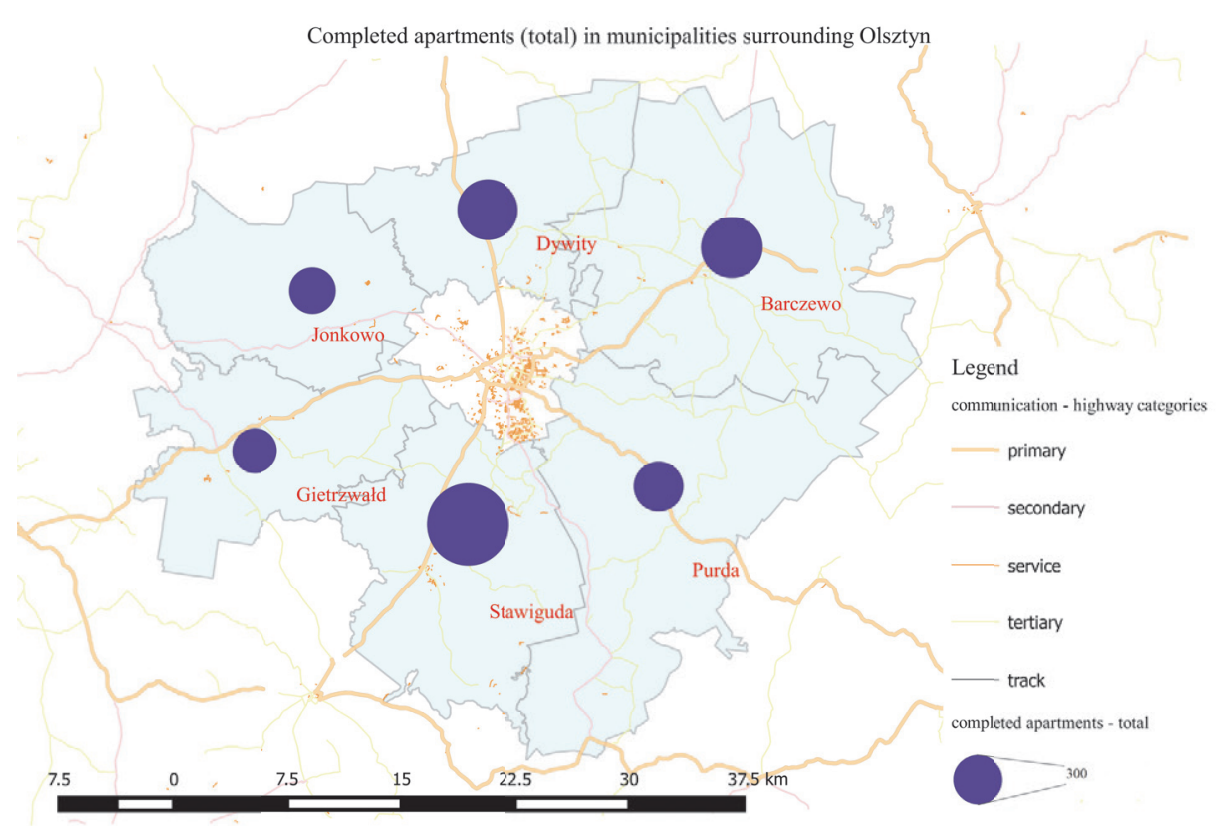

Figure 3a. The number of apartments handed over for occupation during 2010-2014 period 


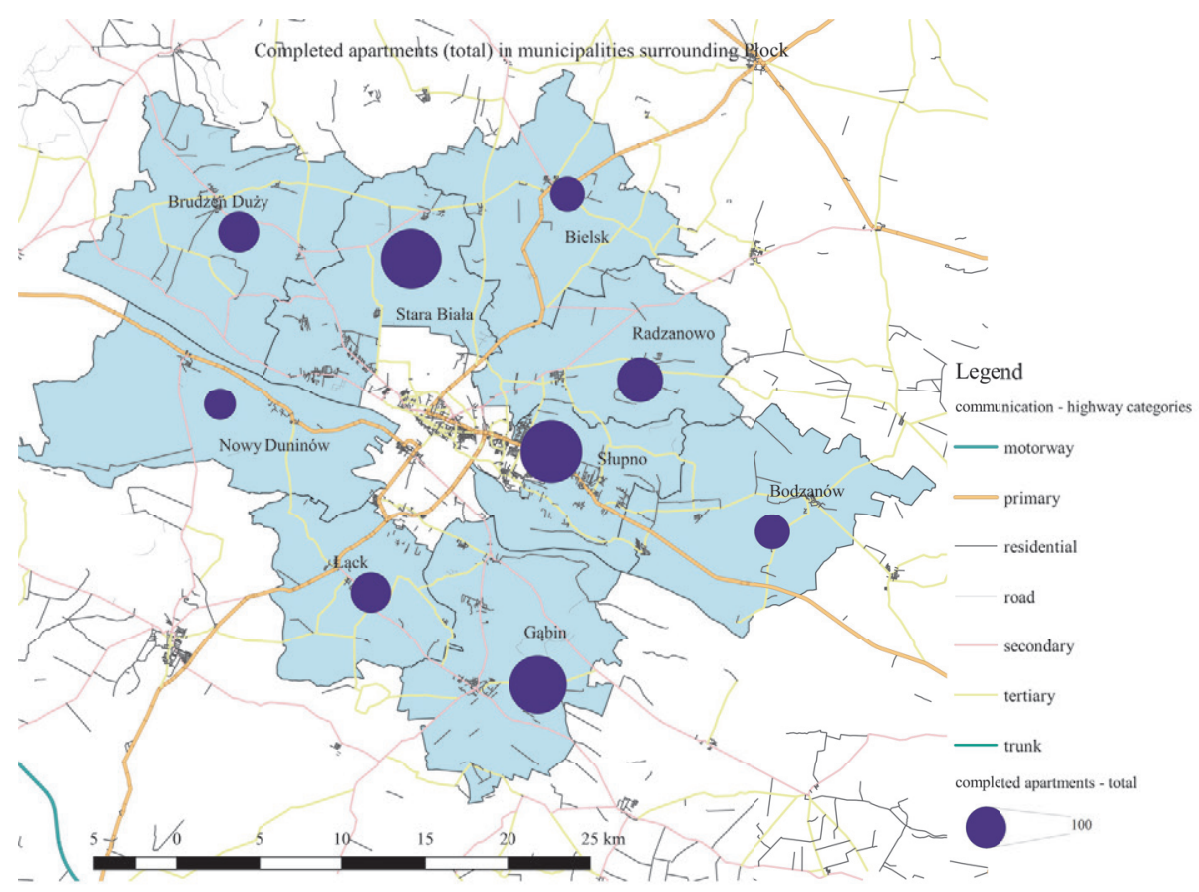

Figure 3b. The number of apartments handed over for occupation during 2010-2014 period

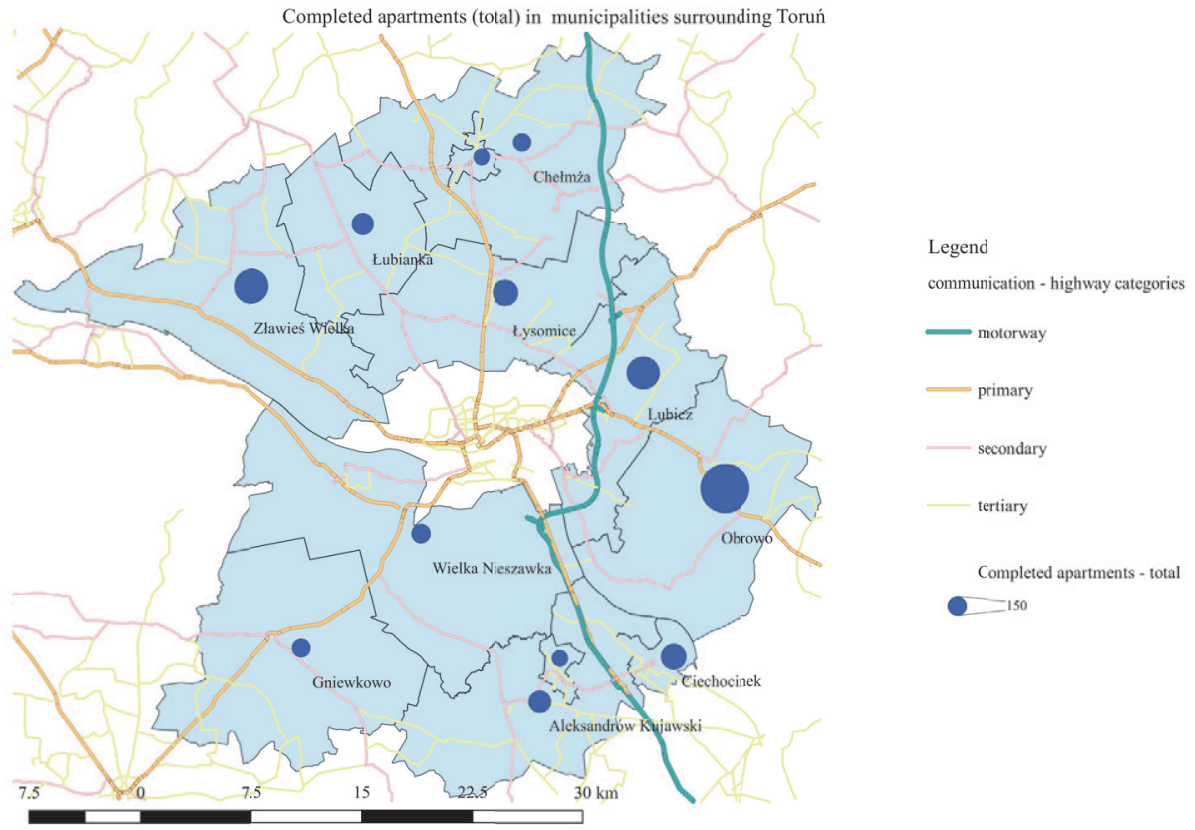

Figure 3c. The number of apartments handed over for occupation during 2010-2014 period 
of analyses prepared for this paper. The circumstances and spatial conditions are equally important, because they stimulate or limit their development. That is why both land use plans and decisions on building conditions for residential buildings were taken into consideration.

The analysis of land use plans consists of two combined values: the total number of plans in the municipality in 2014 and the coverage of the area that these plans affect measured as a proportion (\%). In order to present both these indicators simultaneously the authors opted against the municipal names in Figures $4 a, b$ and $c$.

According to Figure $4 a$, the municipality of Stawiguda has the highest number of valid land use plans, but the coverage is only $9.1 \%$ of the area of the municipality. On the other hand, the municipality of Barczewo has a coverage of $60.2 \%$; however, the number of valid land use plans is half that of Stawiguda. Meanwhile in the suburbs of Płock there are two municipalities with $100 \%$ and almost $100 \%$ coverage by land use plans. These are the municipalities of Słupno and Gqubin. Słupno has also reported the highest number of land use plans (more than 100), so the area covered is more subdivided (Fig. 4b). Meanwhile, in the separate area surrounding Torun there is one municipality with the highest number of the land use plans as well as the highest percentage of coverage. This is Chełmża - a rural municipality (Fig. 4c). This municipality has both a motorway and a primary route within its borders. There is a municipality with a similar number of plans - Zławieś Wielka, but with ten times less coverage.

The last indicator taken into account is the number of decisions on building conditions for residential buildings. Purda is the municipality that has received the largest pressure from developers applying for building conditions in the suburbs of Olsztyn. The total number of decisions made is 861 - the highest value (Fig. 5a). The same indicator measured in the suburbs of Płock gives values that are half that number (Fig. 5b.). There are almost

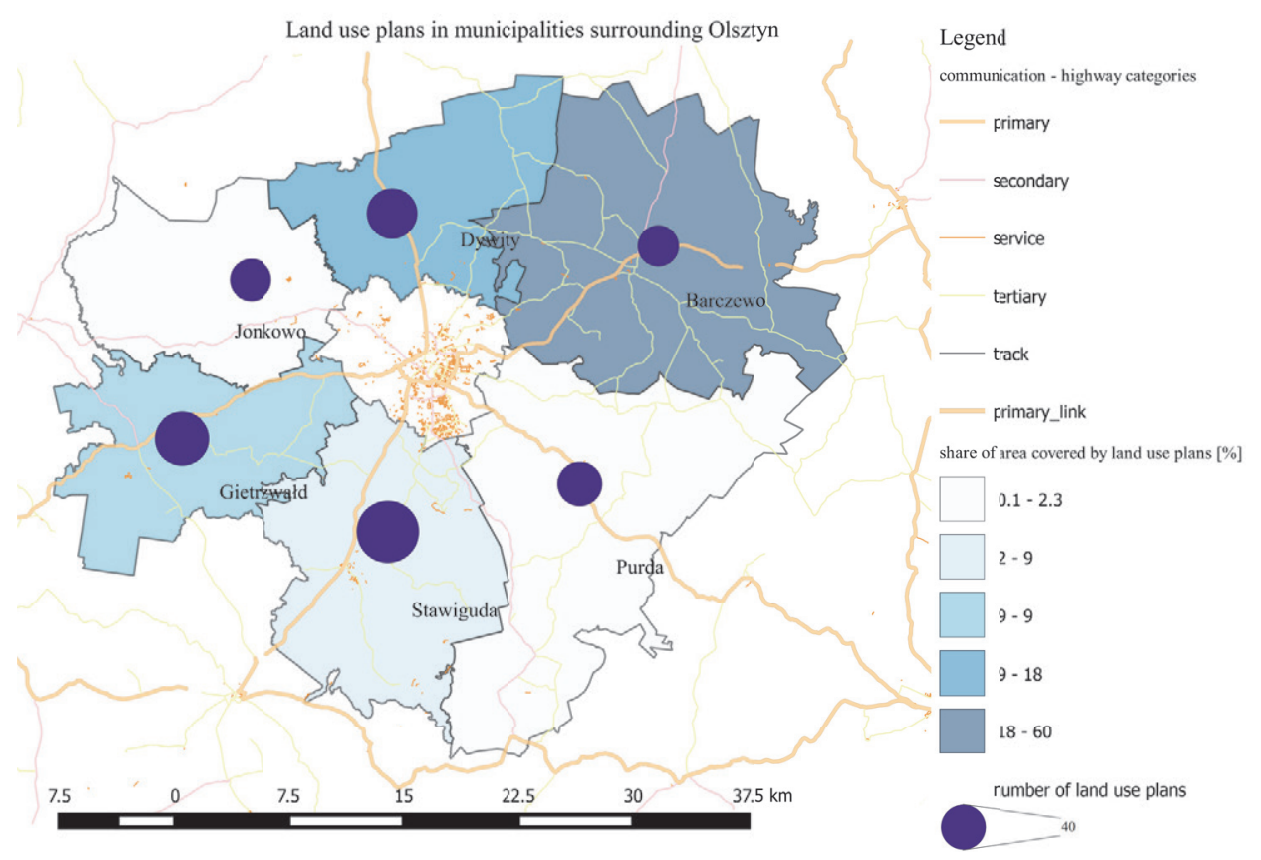

Figure 4a. The number of land use plans and their coverage of the area of the municipality (\%) in 2014 


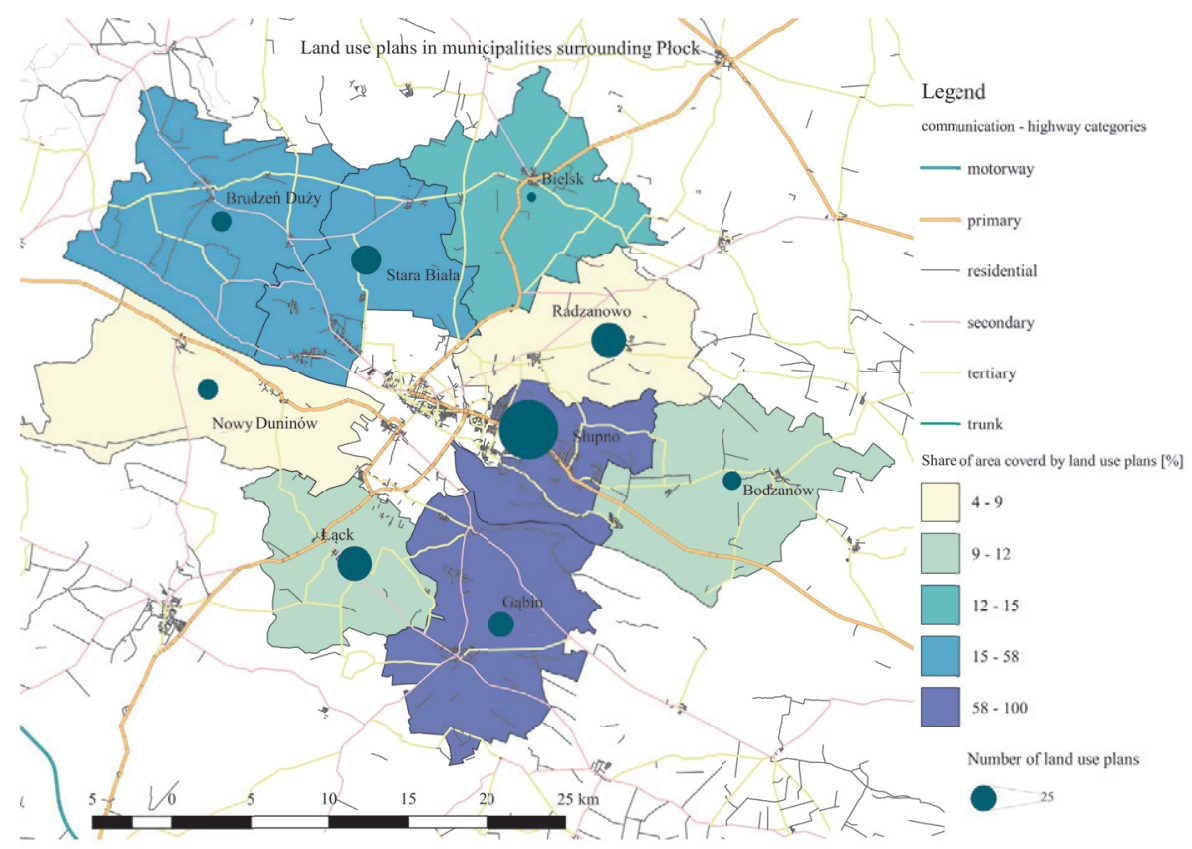

Figure 4b. The number of land use plans and their coverage of the area of the municipality (\%) in 2014

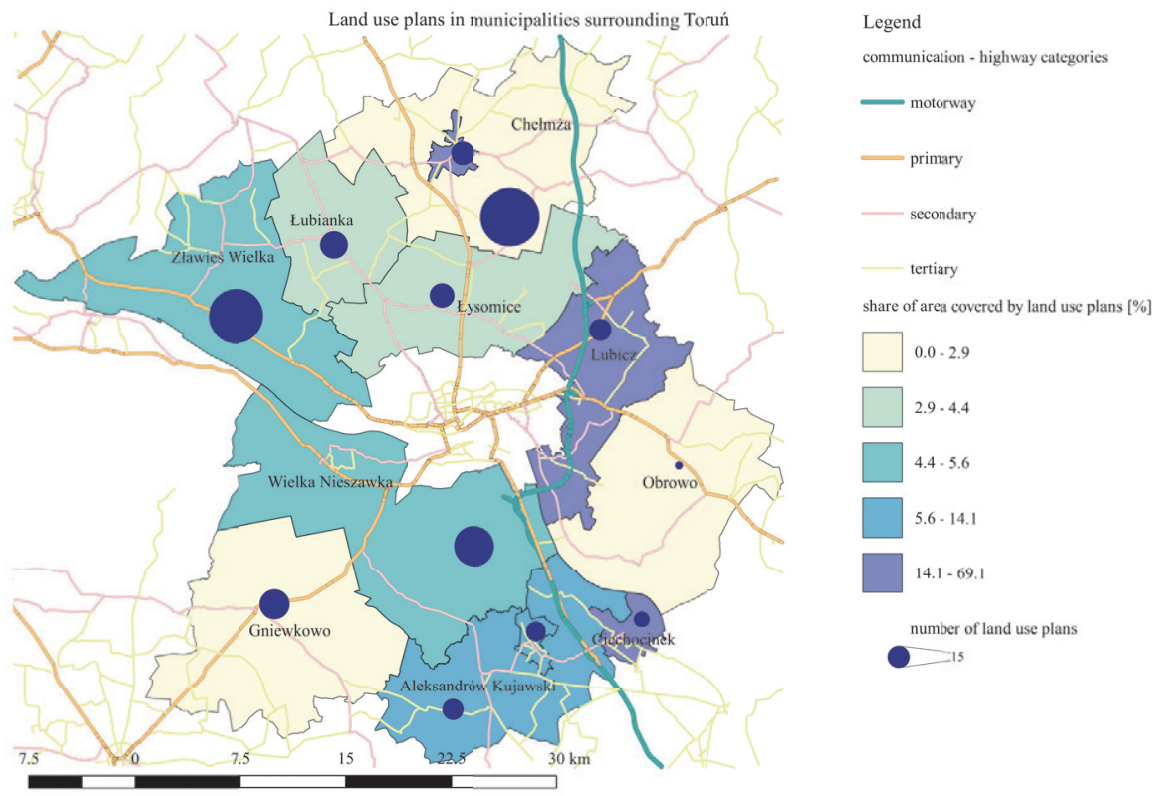

Figure 4c. The number of land use plans and their coverage of the area of the municipality (\%) in 2014 


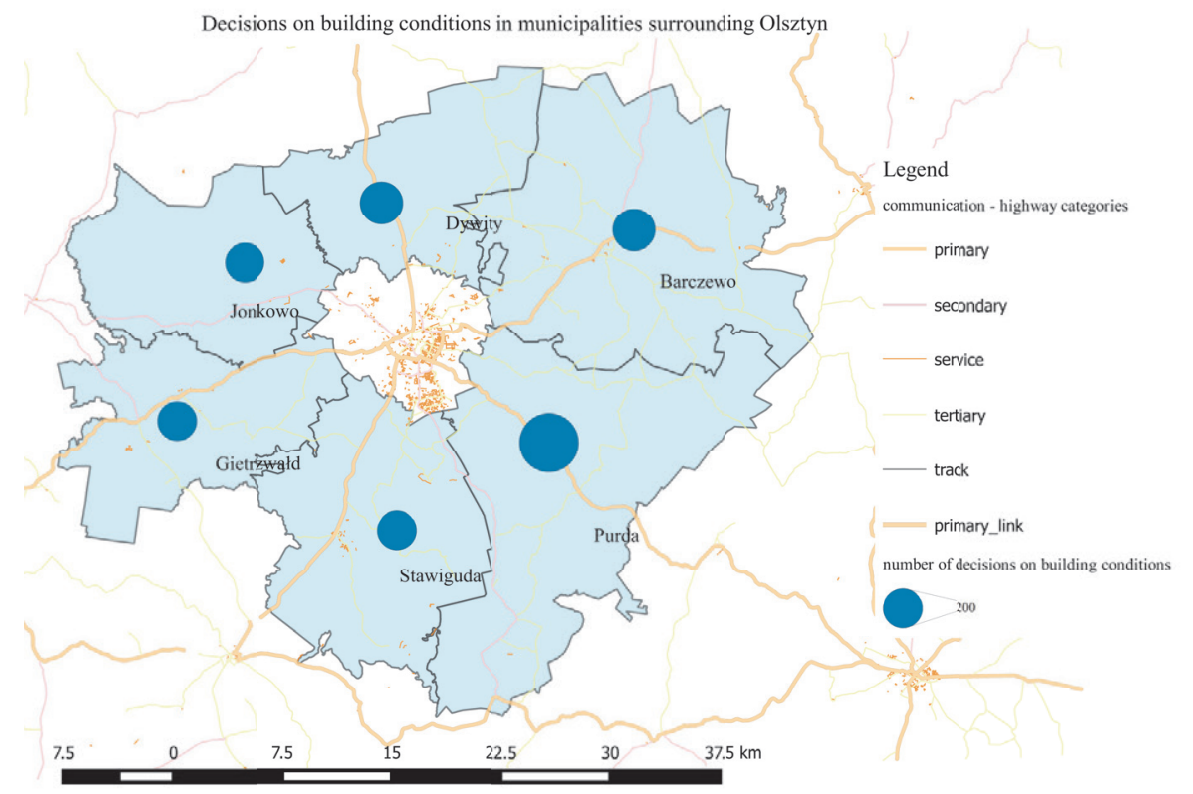

Figure 5a. The number of decisions on building conditions for residential buildings during 2010-2014 period

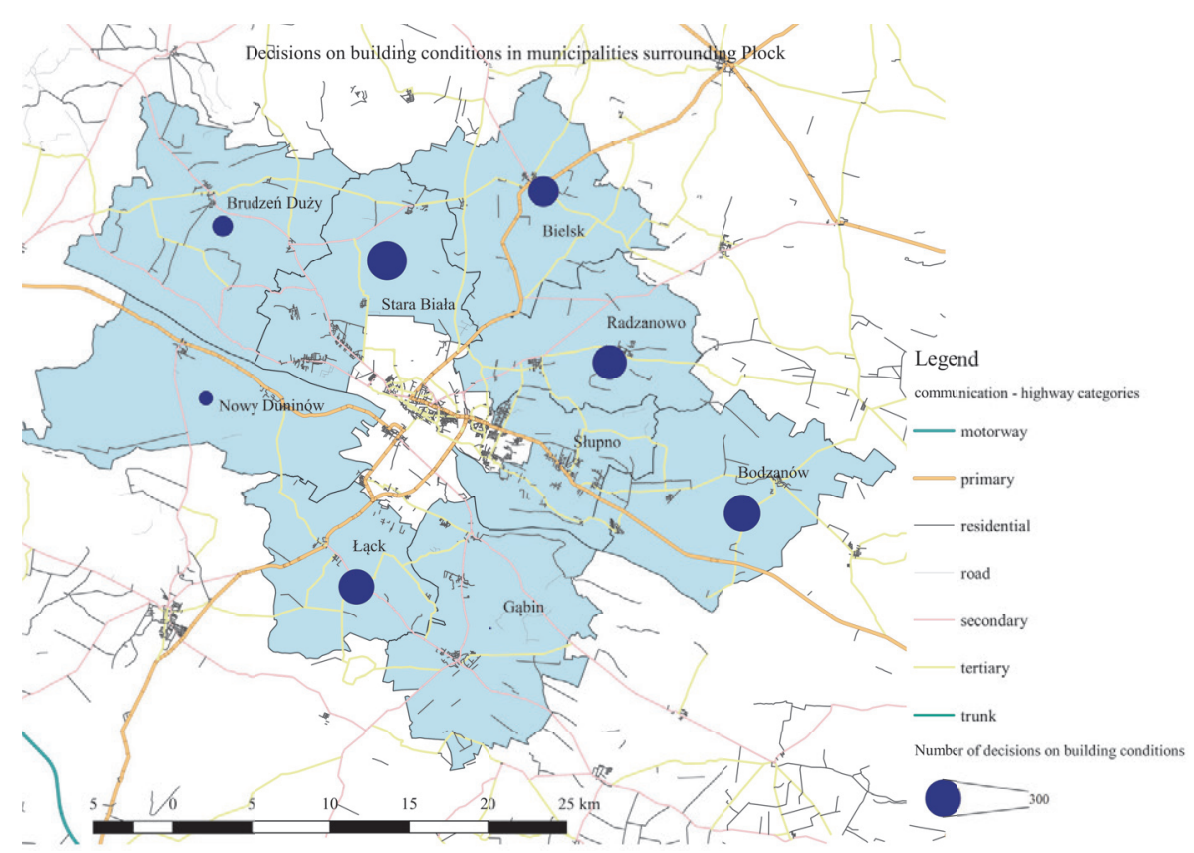

Figure 5b. The number of decisions on building conditions for residential buildings during 2010-2014 period 


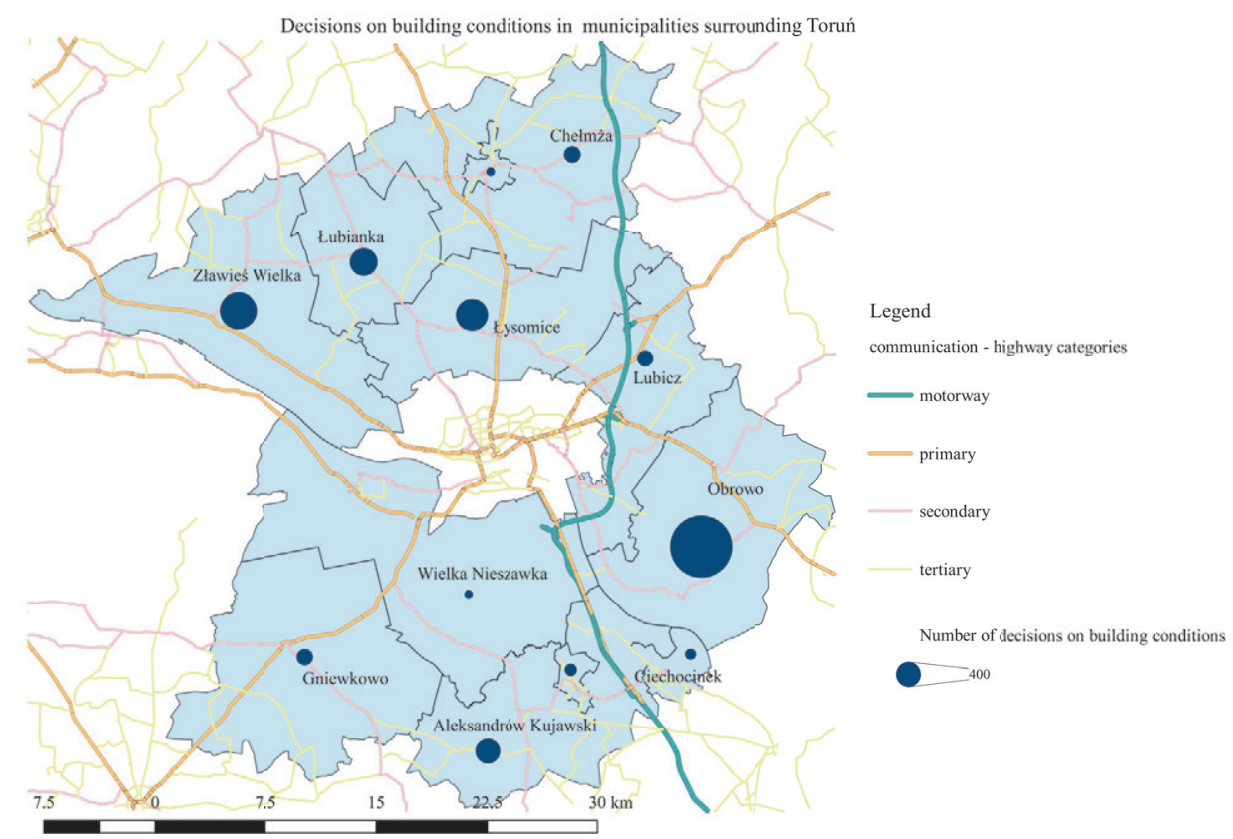

Figure 5c. The number of decisions on building conditions for residential buildings during 2010-2014 period

350 decisions reported in the municipality of Stara Biała. In addition, two other municipalities - Łąck and Bodzanów - have numbers around 300 . However, the rate of making decisions in some municipalities near Torun is significantly above average: Łysomice - 683, Zławieś Wielka - 906, and finally Obrowo with a number of 2568 decisions on building conditions for residential buildings given during the 5-year period (Fig. 5c). It should be emphasised that the land use plans cover a very small area and the pressure for development seems to be really strong.

Summarising the values analysed for selected indicators, the highest rates are reported in municipalities that are usually well connected with the city core. On the other hand, the lowest values of some indicators have been obtained in some municipalities with only secondary roads as the highest level of road in the area of the municipality, such as Jonkowo in the suburbs of Olsztyn. This has low values for the increase in the number of residential buildings, the number of apartments handed over for occupation and the coverage and number of land use plans. The situation in Brudzeń Duży - a municipality near Płock, and Łubianka, situated in the suburbs of Torun is similar, yet the results are higher when comparing them with other data from the area being studied.

However, there are also municipalities where good transportation linkages did not result in the development of housing estates. These are Nowy Duninów, neighbouring Płock and Wielka Nieszawka, bordering Toruń to the south. Despite this, almost the entire area of the municipality of Nowy Duninów is situated within the borders of a landscape park. Likewise, in the municipality of Wielka Nieszawka, there are significant forest complexes where development is excluded. Although the results received in detailed analyses confirm the interdependence between the development of housing estates in the suburbs and a communication system based on high category roads, there are exceptions. They occurred because good transportation links 
with the city core are important determinants of suburban development, but there are also other factors as well as restrictions.

In this study data for entire suburban municipalities has been used. There is a limitation with regard to the analyses conducted for each settlement resulting from access to statistical data. The lowest level of data required is NUTS 5 (municipalities). The area of analyses seems too extensive and internally heterogeneous, consisting of more settlements and building enclaves. Still, it was difficult to report data for settlements and their territories, while the statistical data and land registries (where other data for e.g. precincts are collected) have not been integrated so far. Moreover, the analyses within the ' $1 \mathrm{~km}$ square grid' suggested by the Polish CSO are not appropriate for suburban settlements. Obviously, the results for building enclaves would be more illustrative and clearer evidence therefore there is a great need to introduce a Land Administration System, with integrated data down to real estate size, points and buildings.
Otherwise, the researchers, in our opinion, would be forced to collect detailed data from each municipality at a local scale, which significantly hinders and retards studies.

The last part of the study is a case study analysis which was used to describe the spatial conflict caused by the construction of a ring road in the suburbs of Olsztyn - part of the research area. As the transportation system often determines the development of the suburbs, its transformation may cause objections from the community that is under the influence of the communication system. Such a situation occurs when a supraregional investment such as a ring road is implemented.

The situation presented in this paper took place several years ago and a solution has finally been identified. While designing the Olsztyn ring road, one of the sections in the northern part was routed through recently developed housing estates and an area designated for development and already subdivided into plots. A planned public investment, a new primary school, was built in one of the

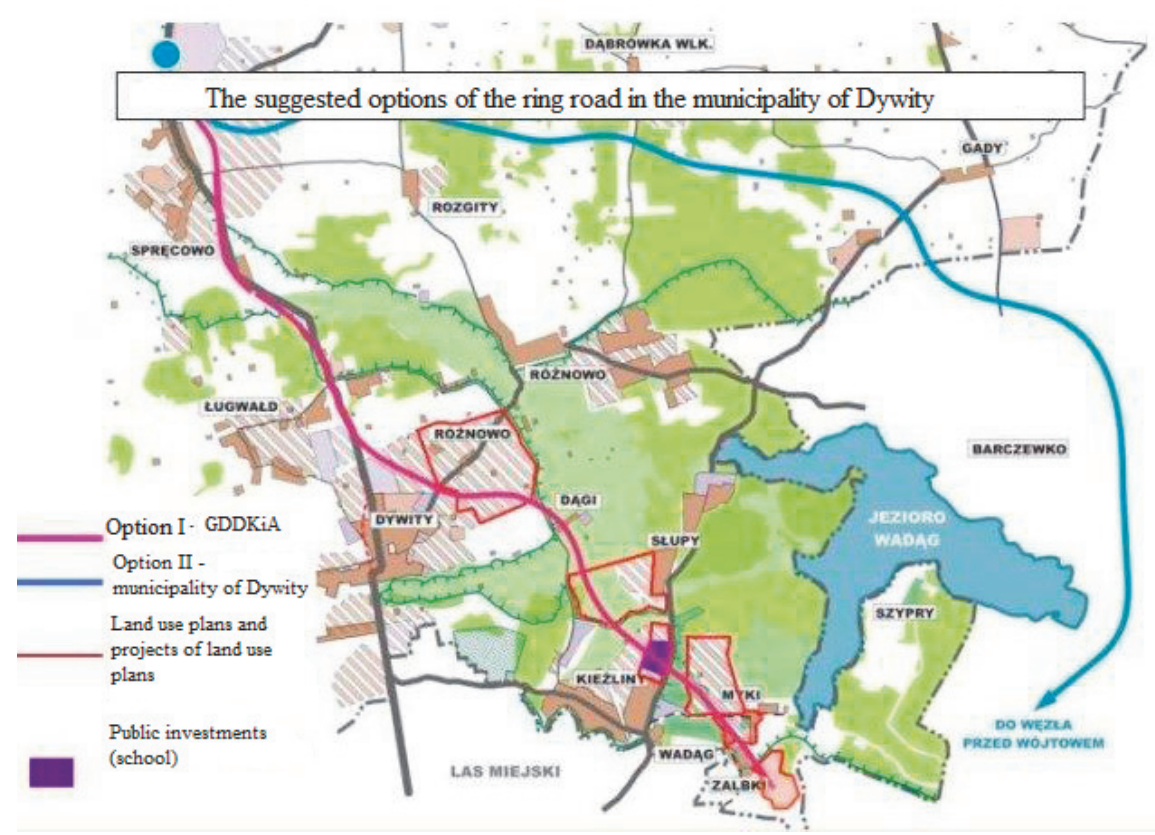

Figure 6. The area of spatial conflict caused by different options for the ring road in suburbs of Olsztyn Source: based on Gmina Dywity 2014. 
villages as a response to the increase in population, particularly children.

This project affected the area of the municipality of Dywity. Therefore, the local authorities along with the local community represented by, among others, local associations, decided to effect a change in the project. This situation created a spatial conflict. That is why different options of the ring road were discussed in order to solve the problem and reach a compromise. Two of those options proposed by General Director for National Roads and Motorways as well as the municipality of Dywity have been compared and analysed (Fig. 6). Such situations occur frequently. For instance, on the south side of Olsztyn, several sections of the southern part of the ring road were investigated, but agreement was reached within a shorter period of time. There, the construction phase of this part of the ring road has just begun.

The compromise between the local community, the authorities and the General Director for National Roads and Motorways as developer seems to have finally been reached. However, it should be stated that the more suburbs develop, the more difficulties may occur when carrying out large scale investments, such as a ring road for the city. It is necessary for designers and investors to update plans and projects prepared for this kind of investment in order to avoid delays. They should coordinate this process with special concern for the level of development, particularly taking account of housing.

\section{Conclusions}

The hypothesis posed states that the development of the suburbs is determined by good communication linkages. However, traffic congestion increases as a result of rapid development of the suburbs. The demand for the transformation of the communication system increases. However, any kind of accessibility measures applied to the improvement of this system should be sensitive to changes in the quality of transport services (transport component), the amount and distribution of the supply of and demand for opportunities (land-use component) and temporal constraints (temporal component) (Geurs \& van Wee 2004). Following the changes in local and regional road communication, including higher category roads, a new area that is well connected to the city arises (Fig. 7).

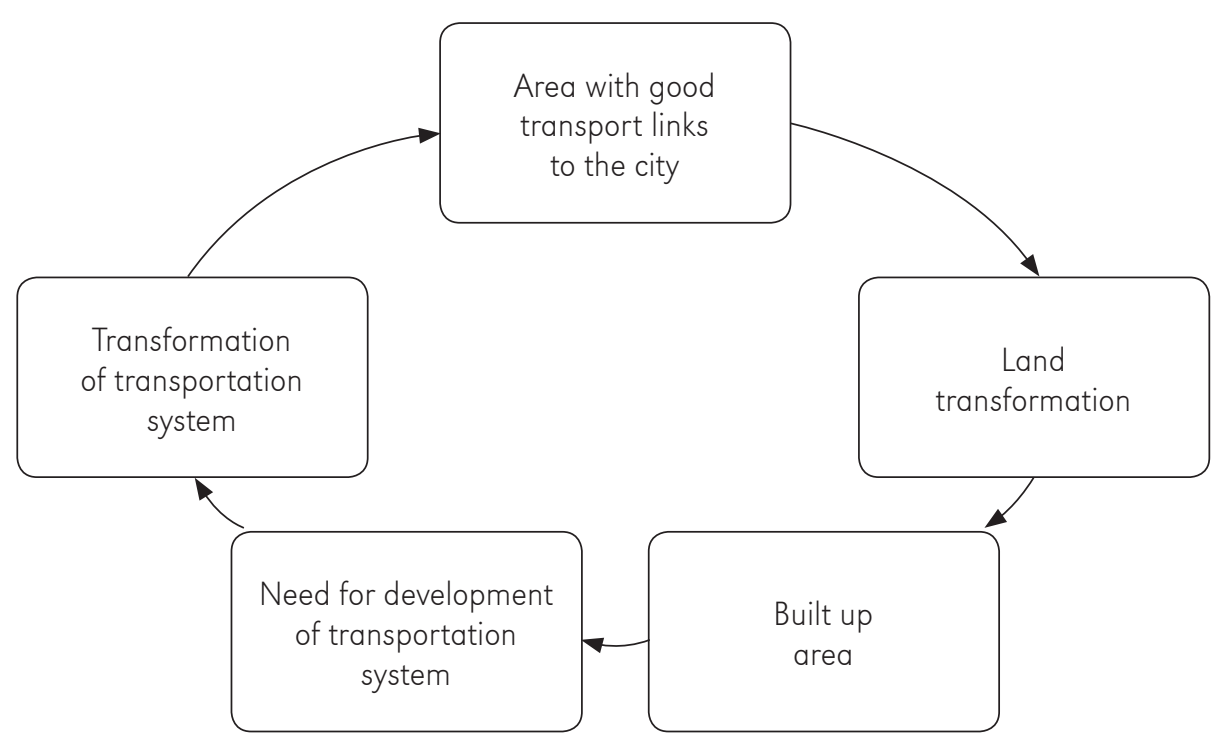

Figure 7. Interdependency between suburbanisation and the development of communication 
As a result of previous studies conducted for the Warsaw Metropolitan Area (Degórska 2012), it was found that changes in coverage revealed that rural areas up to a distance of around $25 \mathrm{~km}$ from the centre of Warsaw displayed an overall trend of increase in areas of land affected by the process of spatial and residential urbanisation. This trend becomes less and less marked at greater distances. Beyond $40 \mathrm{~km}$ from the centre of Warsaw, a considerable weakening of the influence that distance is able to exert on changes in coverage has been observed. Referring to this distance determines land development, but the quality of the transportation system also has a significant impact on the development of suburbs. According to Baum-Snow (2006) new highways affect urban form by causing the population to spread out along highways, but the change in the land use along primary and secondary roads differs as well. The road category does matter.

The inclusion of different dimensions of accessibility constitutes, in the applied perspective, a premise for planning decisions and the setting of priorities as regards investment projects in road transport (Rosik \& Stępniak 2015).

To summarize, the suburbs of Polish cities are subjected to the process of transformation both in the area of land development and communication systems. These processes are linked, which is why the interdependence between the development of housing estates and road communication is observed in the area selected for research in this paper. The analyses conducted for the purpose of this study led to the following conclusions:

1. The areas surrounding Polish cities are subjected to the spatial causes of urban sprawl;

2. The development of suburban housing depending on communication may lead to a rise in intense local traffic and influence the environment;

3. The development of suburbs should be more strictly controlled through the use of land use plans, especially where the undeveloped area is near to the main routes. The existence of a land use plan seems to be a hindrance to the disproportionate building of suburban houses, but there are municipalities subjected to suburbanisation processes where the provision of land use plans is lagging behind the development process;

4. The transformation of transportation systems in suburban areas may result in spatial conflicts - in particular while planning a ring road;

5. As the transformation of land use and the investment process in the suburbs advance, local and regional planning regarding the transformation of the transportation system should be both updated and coordinated with these processes;

6. The improvement of the local transportation system should result in more compact suburban settlements.

Although local circumstances may differ, these conclusions reflect the problem that is observed. There may be some doubts and other threads:

- Whether the chosen city is the only city that affects the surrounding area (some of the municipalities near Torun might also be in the zone of influence of Bydgoszcz a city that does have important administrative functions in this province)?

- Are there any differences between an urban municipality, a rural municipality and a rural-urban municipality?

- Is commuting by car the most popular means of commuting in the area examined? These are the prerequisites for further detailed research. It is also clear that different population groups have migrated to different suburban destinations, future research on commuting should take into account the location or settlement type of the place of residence of commuters (Krisjane et al. 2012). As 'suburban sprawl' seems to be one of the relevant problems, there is a demand to apply various methods and approaches for analysing this process.

Editors' note:

Unless otherwise stated, the sources of tables and figures are the authors', on the basis of their own research. 


\section{References}

BAŃSKI J., 2006. Geografia polskiej wsi. Warszawa: Polskie Wydawnictwo Ekonomiczne.

Baum-Snow N., 2007. Suburbanization and transportation in the monocentric model. Journal of Urban Economics, vol. 62, no. 3, pp. 405-423.

Burneika D., Ubareviciene R., 2015. Spatial transformation of the economy in the postcommunist period: The case of the Vilnius urban region. Geographia Polonica, vol. 88, no. 1, pp. 143-157.

BUtLeR T., 2007. Re-urbanizing London Docklands: Gentrification, Suburbanization or New Urbanism? International Journal of Urban and Regional Research, vol. 31, no. 4, pp. 759-781.

CHIN N., 2002. Unearthing the roots of urban sprawl: A critical analysis of form, function and methodology. Paper 47, London: Centre for Advanced Spatial Analysis. University College London.

CODGK, 2015. Centralny Ośrodek Dokumentacji Geodezyjnej i Kartograficznej. http://www.codgik. gov.pl/ [1 October 2015].

CSO, 2014. Miasta największe pod względem liczby ludności. Warsaw: Central Statistical Office of Poland, http://stat.gov.pl/statystykaregionalna/rankingi-statystyczne/miastanajwieksze-pod-wzgledem-liczby-ludnosci/ [14 October 2015].

DegóRSKA B., 2012. Spatial growth of urbanised land within the Warsaw Metropolitan Area in the first decade of the 21st century. Geographia Polonica, vol. 85, no. 3, pp. 77-95.

Galster G., Hanson R., Ratcliffe M.R., Wolman H., Coleman S., FreiHage J., 2001. Wrestling sprawl to the ground: Defining and measuring an elusive concept. Housing Policy Debate, vol. 12, no. 4, pp. 681-717.

Geurs K.T., van Wee B. 2004. Accessibility evaluation of land-use and transport strategies: review and research directions. Journal of Transport geography, vol. 12, no. 2, pp. 127-140.

Geurs K.T., van Wee B., 2006. Ex-post evaluation of thirty years of compact urban development in the Netherlands. Urban Studies, vol. 43, no. 1, pp. 139-160.

GMINA DYwITY, 2014. http://www.gminadywity/pl [31 December 2014].
Kotus J., 2006. Changes in the spatial structure of a large Polish city - The case of Poznań. Cities, vol. 23, no. 5, pp. 364-381.

Kronenberg J., Bergier T. (eds.), 2010. Wyzwania zrównoważonego rozwoju w Polsce. Kraków: Fundacja Sendzimira.

Krisjane Z., Berzins M., Ivlevs A., Bauls A., 2012. Who are the typical commuters in the post-socialist metropolis? The case of Riga, Latvia. Cities, vol. 29, no. 5, pp. 334-340.

KUBEŠ J., 2015. Analysis of regulation of residential suburbanisation in hinterland of post-socialist 'one hundred thousands' city of České Budějovice. Bulletin of Geography. Socio-economic Series, vol. 27, no. 27, pp. 109-131.

LDB, 2015. Local Data Bank. https://geo.stat.gov. pl/en/bdl [1 October 2015].

LORENS P. 2005 Suburbanizacja w procesie rozwoju miasta postsocjalistycznego [in:] P. Lorens (ed.), Problem suburbanizacji, Biblioteka Urbanisty, 7, Warszawa: Urbanista, pp. 33-44.

McConnell V., Walls M., Kopits E., 2006. Zoning, TDRs and the density of development. Journal of Urban Economics, vol. 59, no. 3, pp. 440-457.

OSM, 2015. Open Street Map, https://www.openstreetmap.org [12 October 2015].

Rosik P., Stępniak M., 2015. Monitoring of changes in road potential accessibility at municipality level in Poland, 1995-2015. Geographia Polonica, vol. 88, no. 4, pp. 607-620.

Senetra A., Szczapańska A., Wasilewicz-PszczótKOWSKA M., 2014. Analysis of changes in the land use structure of developed and urban areas in Eastern Poland. Bulletin of Geography. Socio-economic Series, vol. 24, no. 24, pp. 219-230.

SÝKORA L., OuŘEDní̌EK M., 2007. Sprawling postcommunist metropolis: Commercial and residential suburbanization in Prague and Brno, the Czech Republic [in:] E. RazIN, M. Disst, C. VÁzquez (eds.), Employment deconcentration in European metropolitan areas, Dordrecht: Springer, pp. 209-233.

TIMÁr J., VÁRADI M.M., 2001. The uneven development of suburbanization during transition in Hungary. European Urban and Regional Studies, vol. 8, no. 4, pp. 349-360.

TAmmaru, T. 2005. Suburbanisation, employment change, and commuting in the Tallinn 
metropolitan area. Environment and Planning A, vol. 37, no. 9, pp.1669-1687.

THOMPSON D., 2013. Suburban sprawl: Exposing hidden costs, identifying innovations. Ottawa: Sustainable Properties, http://thecostofsprawl. com/report/SP_SuburbanSprawl_Oct2013_opt. pdf [1 October 2015]. 